\title{
5-HT IA Autoreceptors in the Dorsal Raphe Nucleus Convey Vulnerability to Compulsive Cocaine Seeking
}

\author{
In-Jee You*,I,2, Sherie R Wright ${ }^{2}$, Alvaro L Garcia-Garcia ${ }^{3}$, Andrew R Tapper', Paul D Gardner', \\ George F Koob ${ }^{4,5}$, E David Leonardo ${ }^{3,6}$, Laura M Bohn ${ }^{2}$ and Sunmee Wee ${ }^{2}$ \\ 'Department of Psychiatry, Brudnick Neuropsychiatric Research Institute, University of Massachusetts Medical School, Worcester, MA, USA; \\ ${ }^{2}$ Department of Molecular Therapeutics, The Scripps Research Institute-Florida, Jupiter, FL, USA; ${ }^{3}$ Department of Psychiatry, Columbia University, \\ New York, NY, USA; ${ }^{4}$ Committee on the Neurobiology of Addictive Disorders, The Scripps Research Institute, La Jolla, CA, USA; ${ }^{5}$ National Institute \\ on Alcohol Abuse and Alcoholism, Rockville, MD, USA; ${ }^{6}$ New York State Psychiatric Institute, New York, NY, USA
}

\begin{abstract}
Cocaine addiction and depression are comorbid disorders. Although it is well recognized that 5-hydroxytryptamine (5-HT; serotonin) plays a central role in depression, our understanding of its role in addiction is notably lacking. The 5-HT system in the brain is carefully controlled by a combined process of regulating 5-HT neuron firing through 5-HT autoreceptors, neurotransmitter release, enzymatic degradation, and reuptake by transporters. This study tests the hypothesis that activation of 5-HTIA autoreceptors, which would lessen 5-HT neuron firing, contributes to cocaine-seeking behaviors. Using 5-HT neuron-specific reduction of 5-HTIA autoreceptor gene expression in mice, we demonstrate that 5-HTIA autoreceptors are necessary for cocaine conditioned place preference. In addition, using designer receptors exclusively activated by designer drugs (DREADDs) technology, we found that stimulation of the serotonergic dorsal raphe nucleus (DRN) afferents to the nucleus accumbens (NAc) abolishes cocaine reward and promotes antidepressive-like behaviors. Finally, using a rat model of compulsive-like cocaine self-administration, we found that inhibition of dorsal raphe 5-HT IA autoreceptors attenuates cocaine selfadministration in rats with $6 \mathrm{~h}$ extended access, but not $\mathrm{I} \mathrm{h}$ access to the drug. Therefore, our findings suggest an important role for 5- $\mathrm{HT}_{\text {IA }}$ autoreceptors, and thus DRN $\rightarrow$ NAc 5-HT neuronal activity, in the etiology and vulnerability to cocaine reward and addiction. Moreover, our findings support a strategy for antagonizing 5-HT IA autoreceptors for treating cocaine addiction. Neuropsychopharmacology (2016) 4I, I210-1222; doi:I0.1038/npp.2015.268; published online 7 October 2015
\end{abstract}

\section{INTRODUCTION}

Cocaine ranks as the foremost cause of drug-related emergency department visits in the United States (Substance Abuse and Mental Health Services Administration, 2012) and ranks third in abuse, following marijuana and prescription drugs (Substance Abuse and Mental Health Services Administration, 2013). Drug abuse is highly comorbid with mental disorders, occurring three times more frequently with major depression (Substance Abuse and Mental Health Services Administration, 2013). Adults with depression abuse cocaine more than twice as often as healthy adults (Substance Abuse and Mental Health Services Administration, 2013). Moreover, comorbid depression is a significant risk factor for relapse in cocaine addiction (Hasin et al, 2002; Poling et al, 2007). These findings strongly suggest that cocaine addiction and depression may utilize similar brain circuitry, and this might explain the common comorbidity of these two conditions.

* Correspondence: Dr I-J You, Department of Psychiatry, Brudnick Neuropsychiatric Research Institute, University of Massachusetts Medical School, Worcester, MA 0I604, USA, Tel: + I 508455 4293, Fax: + I 508455 428I, E-mail: In-Jee.You@umassmed.edu

Received 26 May 2015; revised 2 August 2015; accepted II August 2015; accepted article preview online I September 2015
Identifying the factors that simultaneously predispose individuals to cocaine addiction and depression is critical for the development of effective therapies of addiction in patients with depression.

The neurotransmitter 5-hydroxytryptamine (5-HT; serotonin) plays a key role in depression (Bruchas et al, 2011; Robinson et al, 1989; Stockmeier et al, 1998; Valentino et al, 2010). Although the mechanism remains unclear, the clinical efficacy of major antidepressants is thought to depend on the adaptive response of 5-HT neuronal activity (Blier et al, 1998). Cocaine also acutely increases brain $5-\mathrm{HT}$ by inhibiting serotonin reuptake. Most 5-HT neurons, which project to the forebrain, reside in the dorsal raphe nucleus (DRN) (Chang et al, 2011; Jacobs and Azmitia, 1992; Peyron et al, 1998; Waselus et al, 2011). Studies support an important role for raphe 5-HT neurons in depression, stress-related disorders, and drug addiction (Kirby et al, 2008; Land et al, 2009; Valentino et al, 2010). For example, the inhibition of 5-HT neurons by a $\kappa$-opioid receptor agonist was associated with stress-induced cocaine seeking (Land et al, 2009). Furthermore, the deletion of p38 $\alpha$ mitogen-activated protein kinase (MAPK) in 5-HT neurons abolished depressive and cocaine-seeking behavior in mice (Bruchas et al, 2011). The inhibition of raphe 5-HT neuron activity also increased ethanol drinking in rats (Tomkins et al, 1994). Wistar Kyoto rats, a genetic rodent model of 
depression, with high dynorphin activity, exhibit a decrease in 5-HT neuronal excitability in the DRN (Lemos et al, 2011). Thus, it is important to understand the regulatory determinants of 5-HT neuron activity in an effort to identify molecular targets for novel addiction and neuropsychiatric disorder therapies.

Among 5-HT receptors (Filip et al, 2005; Fink and Gothert, 2007), 5- $\mathrm{HT}_{1 \mathrm{~A}}$ receptors directly control the cell firing of 5-HT neurons as somatic inhibitory autoreceptors (ie, 5-HT receptors on 5-HT neurons) (Haj-Dahmane et al, 1991; Sprouse and Aghajanian, 1987) and govern overall 5 -HT tone in the brain. Consequently, the activity of $5-\mathrm{HT}_{1 \mathrm{~A}}$ autoreceptors greatly influences the actions of other 5-HT receptors (Popova and Naumenko, 2013). A polymorphism that leads to an increase in $5-\mathrm{HT}_{1 \mathrm{~A}}$ autoreceptors is linked to individual vulnerability to depression in humans (Kishi et al, 2009; Le Francois et al, 2008). In addition, the 5- $\mathrm{HT}_{1 \mathrm{~A}}$ autoreceptors affect the expression of cocaine-produced open field behavioral responses (Carey et al, 2005). Despite the importance of $5-\mathrm{HT}_{1 \mathrm{~A}}$ autoreceptors in the 5 -HT system, our understanding of the role of $5-\mathrm{HT}_{1 \mathrm{~A}}$ autoreceptors in addiction is lacking, most likely because 5$\mathrm{HT}_{1 \mathrm{~A}}$ receptors are also densely expressed as heteroreceptors (ie, 5-HT receptors on non-5-HT neurons) (Fink and Gothert, 2007), producing opposite actions on mood (Albert and Fiori, 2013). These two 5- $\mathrm{HT}_{1 \mathrm{~A}}$ receptor populations are difficult to dissect pharmacologically.

Previous studies demonstrated a relationship between $5-\mathrm{HT}_{1 \mathrm{~A}}$ receptors and the acute reinforcing effects of cocaine (Czoty et al, 2005; Gold and Balster, 1992; Homberg et al, 2004; Peltier and Schenk, 1993). Systemic administration of buspirone, a $5-\mathrm{HT}_{1 \mathrm{~A}}$ receptor partial agonist, was shown to attenuate cocaine seeking-like responding in rats (Shelton et al, 2013). In the present study, we investigated the selective role of $5-\mathrm{HT}_{1 \mathrm{~A}}$ autoreceptors in cocaine reward using a genetic model of $5-\mathrm{HT}_{1 \mathrm{~A}}$ autoreceptor knockdown $\left(5-\mathrm{HT}_{1 \mathrm{~A}}\right.$ autoKD mice), designer receptors exclusively activated by designer drugs (DREADDs), and brain region-selective infusion of antagonists. In the first model, we tested the rewarding properties of cocaine in mice with selective knockdown of 5- $\mathrm{HT}_{1 \mathrm{~A}}$ autoreceptors in the DRN from birth (Richardson-Jones et al, 2011). In the second model, we used DREADDs (Krashes et al, 2011) to determine the role of DRN serotonergic neuron inputs on cocaine conditioned place preference (CPP). In the last model, we tested the effects of DRN infusion of a $5-\mathrm{HT}_{1 \mathrm{~A}}$ antagonist on cocaine self-administration in a rat extended access cocaine selfadministration (long access (LgA) rats) paradigm that allows for an escalating, compulsive-like pattern of cocaine intake. Rats with extended access show heightened motivation for cocaine, resistance to punishment, and dysphoric- and anxiety-like states during abstinence compared with rats with daily short access (ShA) to cocaine, providing face validity and construct validity for modeling compulsive-like responding compared with recreational drug use (Ahmed et al, 2002; Ahmed and Koob, 1998; Aujla et al, 2008; Wee et al, 2007a, b). Using these three rodent models, we provide empirical evidence that $5-\mathrm{HT}_{1 \mathrm{~A}}$ autoreceptors play an important role in the etiology of and vulnerability to cocaine addiction.

\section{MATERIALS AND METHODS}

\section{Animals}

All procedures were conducted in accordance with the National Institutes of Health Guide for the Care and Use of Laboratory Animals 8th edition in 2011 and were approved by the Institutional Animal Care and Use Committee of The Scripps Research Institute. Male 5- $\mathrm{HT}_{1 \mathrm{~A}}$ autoKD mice (Pet1 - $t S^{+} H$ tr $1 a^{\text {tetO/tetO }}$ mice) with a mixed 129 S6/SvEvTac background were generated as described previously (Richardson-Jones et al, 2011). Briefly, Pet-1-tTS ${ }^{+}$trl $a^{\text {tetO/tetO }}$ mice have suppressible $5-\mathrm{HT}_{1 \mathrm{~A}}$ autoreceptors in the DRN and possess two distinct engineered alleles, the tetracycline operator $(t e t O)$ and tetracycline-dependent transcriptional suppressor ( $t T S)$ under the control of the Pet-1 promoter fragment $\left(\right.$ Pet1- $\left.^{-} \mathrm{TS}^{+}\right)$(Richardson-Jones et al, 2011). In the presence of doxycycline, tTS proteins do not bind their target sequence. However, in the absence of doxycycline, tTS proteins bind tet $\mathrm{O}$ sites, inhibiting the expression of $5-\mathrm{HT}_{1 \mathrm{~A}}$ autoreceptors. Therefore, $5-\mathrm{HT}_{1 \mathrm{~A}}$ autoKD were maintained on regular chow, whereas control mice (wild type) were maintained on chow that contained doxycycline $(40 \mathrm{mg} / \mathrm{kg})$. Male hemizygous Fev (fifth Ewing variant, Pet-1 ETS oncogene family)-cre transgenic mice (B6. Cg-Tg (Fev-cre) 1Esd/J; Stock number: 012712; The Jackson Laboratory, Bar Harbor, ME) and wild-type (WT) littermates weighed 22$26 \mathrm{~g}$ at the beginning of the study. Male Wistar rats (Charles River, Hollister, CA) each weighing $225-250 \mathrm{~g}$ at the beginning of the study were used. All rats and mice were housed under a $12 \mathrm{~h} / 12 \mathrm{~h}$ reverse light/dark cycle with lights off at 9:00 AM or 10:00 AM, respectively.

\section{Stereotaxic AAV-DREADD-mCherry Injections}

Fev-Cre and WT littermate controls were anesthetized with isoflurane and placed into a stereotaxic apparatus (KOPF 957, Tujunga, CA). After exposing the skull via incision, a small hole was drilled through the skull for injection. A 33gauge plane microinjector was inserted into the brain and $200 \mathrm{nl}$ bilateral injections were made in the NAc of mice (coordinates, bregma: anterior-posterior, $+1.70 \mathrm{~mm}$; lateral, $\pm 1.2 \mathrm{~mm}$; dorsal-ventral, $-4.4 \mathrm{~mm}$ ). AAV8-hSyn-DIO$\mathrm{hM} 3 \mathrm{D}(\mathrm{Gq})$-mCherry (titer $4.7 \times 10^{\mathrm{e} 12}$ genomes copies per $\mathrm{ml}$ ), AAV8-hSyn-DIO-hM4D(Gi)-mCherry (titer $5.3 \times 10^{\mathrm{e} 12}$ genomes copies per ml), or AAV8-hSyn-DIO-mCherry (titer $3.8 \times 10^{\mathrm{e} 12}$ genomes copies per $\mathrm{ml}$ ) from the University of North Carolina Gene Therapy Center (Chapel Hill, NC) were injected bilaterally into the NAc of 6-week-old Fev-Cre and WT (non-cre-expressing littermates) mice at $25 \mathrm{nl} / \mathrm{min}$. The microinjector was withdrawn $5 \mathrm{~min}$ after injection. For postoperative care, mice were injected orally with Metacam $(0.2 \mathrm{mg} / \mathrm{kg}$; Boehringer Ingelheim, Ridgefield, CT) and subcutaneously with Baytrill $(0.2 \mathrm{mg} / \mathrm{kg}$; Bayer HealthCare, Pittsburgh, PA). Mice were allowed 1 week to recover and then acclimated to handling for 1 week before the start of any behavioral studies. Briefly, designer receptors, mutated muscarinic G protein-coupled receptors (GPCRs), are unable to bind natural neurotransmitters, but can be activated by the pharmacologically inert ligand clozapine- $\mathrm{N}$-oxide (CNO) (Wess et al, 2013). CNO activation of hM3Dq- or hM4Diexpressing neurons results in neuronal excitation via Gq proteins or inhibition via $\mathrm{Gi}$ proteins, respectively 
(Armbruster et al, 2007). Previous studies have reported that systemic injection of CNO activates DREADDs in the brain within $15 \mathrm{~min}$ and reaches the peak after $\sim 30-40 \mathrm{~min}$, with the effect of CNO lasting $9 \mathrm{~h}$ (Alexander et al, 2009; Rogan and Roth, 2011). Thus, animals received systemic injection of CNO $(1 \mathrm{mg} / \mathrm{kg}) 20 \mathrm{~min}$ before cocaine or saline conditioning in the CPP, the elevated plus maze (EPM), the tail suspension test (TST), and the locomotor activity test. In addition, the DREADDs are fused to mCherry to monitor receptor expression. At the conclusion of the study, mice were perfused and decapitated for immunofluorescence.

\section{Cocaine-Induced CPP}

A three-chamber CPP apparatus (Med Associates, Inc., St Albans, VT) was used. Two different compartments were separated by a small gray chamber with guillotine doors. The procedure consisted of a pre-test, conditioning, and a post-test. In the pre- and post-test, the mice were given free access to both compartments, and the time spent in each compartment was recorded as described in Supplementary Methods.

\section{Elevated Plus Maze}

The EPM apparatus (Med Associates, Inc.) consisted of a center platform elevated $40 \mathrm{~cm}$ from the floor, with 4 arms attached: 2 open arms across from each other and 2 closed arms perpendicular to the open arms with a white floor insert. Lighting was 276 lux on open arms, 127 lux on closed arms, and 230 lux in the center. Mice were placed in the center platform facing a closed arm and allowed to freely explore the maze for $5 \mathrm{~min}$. The location of the mice was tracked with an automated video-tracking system (EthoVision XT, Noldus Information Technology, Leesburg, VA). All experimental sessions were conducted under white light illumination and with a white noise filter. The arms were cleaned with $0.1 \%$ Micro-90 (International Products Corporation, Burlington, NJ) before and between trials. The number of entries and time spent in open arms were analyzed.

\section{Tail Suspension Test}

A black acrylic four-chamber TST apparatus (8 inch depth $\times$ 7 inch width $\times 12$ inch height) with a white infrared (IR)-permeable acrylic back was constructed by the Scripps FL Behavior Core. The mouse tail was taped to a hook with white lab tape (VWR 89097-916, Wayne, PA). Movement was monitored for $6 \mathrm{~min}$ and the duration of mouse immobility during the last $4 \mathrm{~min}$ was scored and analyzed using a standard charge-coupled device (CCD) camera and an automated video-tracking system (EthoVision XT). All experimental sessions were conducted under two IR lights and a white noise filter in a dark room. The chambers were cleaned with $0.1 \%$ Micro-90 before and between trials.

\section{Locomotor Activity}

To test for baseline activity, mice were placed into an open field arena (17 inch length $\times 17$ inch width $\times 12$ inch height, created by the Scripps FL Behavior Core) and locomotor behavior was measured for $30 \mathrm{~min}$. The mice were then injected with CNO (1 mg/kg, i.p.) and returned to the arena for $20 \mathrm{~min}$. Before testing, uniformity of light across the arena was confirmed using a light intensity meter. The chambers were cleaned with $0.1 \%$ Micro-90 (International Products corporation) before and between trials. All experimental sessions were conducted under red light illumination and with a white noise filter. The locomotor activity test was conducted and recorded by a computerized video-tracking software program (EthoVision XT). Data were analyzed in 10-min blocks.

\section{Tissue Preparation and Immunofluorescence}

After the CPP test, mice were perfused with $4 \%$ paraformaldehyde. The brains were removed and post-fixed in the same fixation solution for $4 \mathrm{~h}$ at $4{ }^{\circ} \mathrm{C}$ and were dehydrated in $30 \%$ sucrose. Sections $(40 \mu \mathrm{m})$ were cut on a cryostat (Leica, Buffalo Grove, IL) and kept in phosphate-buffered saline (PBS) with $0.1 \%$ sodium azide at $4{ }^{\circ} \mathrm{C}$ before processing for immunofluorescence. The sections were incubated with $0.3 \%$ Triton-X in $1 \times$ PBS for 3 min twice and nonspecific binding was then blocked with $2 \%$ bovine serum albumin (BSA) in $1 \times$ PBS for $30 \mathrm{~min}$ and incubated for 2 days at $4{ }^{\circ} \mathrm{C}(0.1 \%$ Triton-X in 2\% BSA) in goat anti-5-HT transporter antibody (1:800; Abcam), rabbit anti-DsRed antibody (1:2500; Clontech), and rabbit anti-c-fos antibody (1:400; Santa Cruz). Following washes with $1 \times$ PBS, sections were blocked for 30 min with $2 \%$ donkey serum (Sigma) with $2 \%$ BSA in $1 \times$ PBS. The sections were then incubated for $30 \mathrm{~min}$ with Alexa Fluor 488 anti-goat and Alexa Fluor 594 anti-rabbit secondary antibodies (1:1000; Invitrogen). The sections were coverslipped with Vectashield mounting media with DAPI for fluorescence (Vector Laboratories, Burlingame, CA). Fluorescently stained images were collected using confocal microscopy (Zeiss Thornwood, NY). The c-fos immunolabeled profiles were counted in the dorsomedial and ventromedial subregions of the DRN from at one slice per hM3Dq-expressing Cre+ mouse and Cre- mouse. The shape and the base of the aqueduct defined the same area of the dorsomedial and ventromedial subregions of the DRN (Figure 2d). In addition to the DRN, c-fos immunoreactive profiles were quantified in the NAc of one slice per hM3Dqexpressing Cre+ mouse and Cre- mouse. The shape of the forceps minor of the corpus callosum and the location of the anterior commissure defined the same area of the NAc (Figure 2g). For analysis of double immunolabels (DsRed and 5-HT transporter), and three immunolabels (c-fos, 5-HT transporter, and DAPI), individual high-magnification fields were digitally captured, merged, pseudocolored, and examined using Image software (NIH, Bethesda, MD; rsb.info. nih.gov/ij). Because the $\mathrm{c}$-fos immunolabeled nuclear profiles were surrounded by 5 -HT transporter containing fibers, we determined the colocalization of c-fos with 5-HT transporter as the 5-HT transporter immunoreactive neurons contained c-fos immunolabeled nuclear profiles and merged with DAPI, a nuclear counterstain.

\section{Cocaine Self-Administration}

The drugs were tested in separate groups of animals. Eighteen male Wistar rats were intravenously catheterized 
as previously described (Wee et al, 2007b) and trained to self-administer cocaine $(0.5 \mathrm{mg} / \mathrm{kg} /$ infusion $)$ as described in Supplementary Methods. They were then divided into two groups. One group continued to self-administer cocaine with $1 \mathrm{~h}$ access (short-access, ShA, $n=9$ ), whereas the other group self-administered cocaine for $6 \mathrm{~h}$ per day (long-access, LgA, $n=9)$. After $14-15$ sessions of cocaine self-administration with short or long access, the effect of WAY100635, a selective $5-\mathrm{HT}_{1 \mathrm{~A}}$ receptor antagonist, on cocaine selfadministration was examined under a progressive-ratio (PR) schedule as described in Supplementary Methods. All test sessions were separated by at least two fixed-ratio (FR) sessions with either 1 or $6 \mathrm{~h}$ access.

\section{WAY100635 Microinjection in the DRN and Cocaine Self-Administration}

Nineteen male Wistar rats were trained to self-administer cocaine as described above and implanted with intracranial cannulae that ended $2 \mathrm{~mm}$ dorsal to the DRN. After recovery, the rats again self-administered cocaine for $1 \mathrm{~h} /$ day and were then divided into two groups. One group of rats continued to self-administer cocaine with ShA $(n=10)$, whereas the other group was allowed to selfadminister cocaine with $\operatorname{LgA}(n=9)$. After 12 sessions of cocaine self-administration with either ShA or LgA, the effect of WAY100635 $(75,150 \mu \mathrm{g})$ in the DRN on cocaine selfadministration was determined under a PR schedule (Supplementary Methods).

\section{Drugs}

All systemic test drugs were dissolved in saline and administered in a volume of $10 \mathrm{ml} / \mathrm{kg}$ body weight for mouse or $1 \mathrm{ml} / \mathrm{kg}$ body weight for rat. For microinjections, WAY100635 was dissolved in $0.5 \times \mathrm{PBS}(\mathrm{pH} 7.4)$. The doses of all drugs were tested in a counterbalancing order across rats. CNO dissolved in $0.25 \%$ dimethyl sulfoxide and saline was synthesized by Theodore Kamenecka, Associate Scientific Director, at The Scripps Research Institute.

\section{Data Analysis}

The CPP data were expressed as the mean time spent in the CS+ (positive conditioned stimulus; cocaine-conditioned) compartment and CS- compartment (no conditioned stimulus; saline-conditioned) in each pre- and post-test and were analyzed using two-way repeated-measures analysis of variance (ANOVA) followed by the Bonferroni post hoc test (Stimulus $\times$ Test; Prism 5.0, GraphPad, San Diego, CA). The cocaine self-administration data are expressed as the mean number of injections for each group of rats and were analyzed using two-way repeated-measures ANOVA followed by the Bonferroni post hoc test (Access $\times$ Session for escalation data; Access $\times$ Test drug dose for the PR data; Prism 5.0, GraphPad). The TST and the EPM data were analyzed using $t$-tests. The locomotor activity data were expressed as the distance traveled and were analyzed using two-way repeated measures ANOVA followed by the Bonferroni post hoc test (Cre $\times$ Time; Prism 5.0, GraphPad).
When variances differed between two groups, the data were log-transformed and subjected to analysis.

\section{RESULTS}

\section{5-HT ${ }_{1 \mathrm{~A}}$ autoKD Mice Fail to Display CPP to Cocaine}

We first examined the effect that decreased $5-\mathrm{HT}_{1 \mathrm{~A}}$ autoreceptor function in the DRN may have in cocaineinduced CPP using Pet-1-tTS $\mathrm{Htr}^{+} a^{\text {tetO/tetO }}$ mice. To evaluate the effect of doxycycline on cocaine-induced CPP, two groups of mice without the tTS allele $\left(\mathrm{tTS}^{-}\right)$that were on either regular or doxycycline chow were included in the study.

The timeline of the CPP experiment is shown in Figure 1a. Cocaine $(7.5 \mathrm{mg} / \mathrm{kg}$, i.p.) significantly conditioned a place preference in control mice (Figure 1b; Test $\times$ Stimulus interaction $\mathrm{F}_{1,16}=25.63, P<0.001$; Stimulus $\mathrm{F}_{1,16}=0.51$, $P=0.49$; Test $\left.\mathrm{F}_{1,16}=0.00, P=1.00\right)$, whereas it failed to do so in $5-\mathrm{HT}_{1 \mathrm{~A}}$ autoKD mice (Figure 1c; Test $\times$ Stimulus interaction $\mathrm{F}_{1,8}=5.21, \quad P=0.05 ;$ Stimulus $\mathrm{F}_{1,8}=2.86$, $P=0.13$; Test $\left.\mathrm{F}_{1,8}=0.71, \quad P=0.43\right)$. According to our analysis, although there was a trend in Test $\times$ Stimulus interaction, it was not quite statistically significant. Doxycycline chow alone had no effect on cocaine-induced CPP, in which both groups of mice without the tTS allele (tTS ${ }^{-}$) with doxycycline and regular chow developed cocaine-induced CPP. Both groups of $\mathrm{tTS}^{-}$mice with doxycycline chow and regular chow developed cocaine-induced CPP (Figure 1d; tTS $^{-}$DOX-ON Test $\times$Stimulus interaction $\mathrm{F}_{1,8}=7.89$, $P<0.05$; Stimulus $\mathrm{F}_{1,8}=6.57, P<0.05$; Test $\mathrm{F}_{1,8}=0.01$, $P=0.10$; Figure 1e; tTS $^{-}$DOX-OFF Test $\times$Stimulus interaction $\mathrm{F}_{1,8}=13.96, P<0.01$; Stimulus $\mathrm{F}_{1,8}=2.08, P=0.19$; Test $\left.\mathrm{F}_{1,8}=1.58, P=0.24\right)$.

\section{Fev-Cre Transgenic Mice Exclusively Express G Protein-DREADDs in 5-HT Neurons}

Reduced $5-\mathrm{HT}_{1 \mathrm{~A}}$ autoreceptor function increases activity of DRN serotonergic neurons, providing a potential mechanism for resistance to cocaine reward. To test the hypothesis that activation of 5-HT projection neurons from the DRN to the forebrain region including the NAc reduces cocaine reward, we used DREADDs to selectively excite or silence 5-HT neurons from the DRN to the NAc and examined its impact on cocaine CPP. We used a cre-dependent adeno-associated virus (AAV) serotype 8 to target hM3Dq and hM4Di specifically to DRN 5-HT neurons projecting to the NAc. This was accomplished by bilateral injection of AAV8hM3Dq or -hM4Di-mCherry viral particles into the NAc of Fev-cre transgenic mice that express cre-recombinase in all mid-hindbrain 5-HT-synthesizing neurons and their postmitotic precursors. At 6 weeks after infection, mCherry was detected exclusively in the DRN serotonergic cell bodies (Figure 2a) and the 5-HT neuron terminals innervating the NAc (Figure 2b) based on colocalization with the serotonergic marker, the serotonin transporter (SERT), confirming retrograde infection by AAV8 viral particles. Verifying the specificity of mCherry expression in 5-HT neurons in hM3Dq expressing Fev-cre (Cre+) mice, mCherry could not be detected in WT littermate mice (non-cre-expressing mice, Cre- ) injected with the same virus (Figure $2 \mathrm{a}$ and $\mathrm{b}$ ). 
a

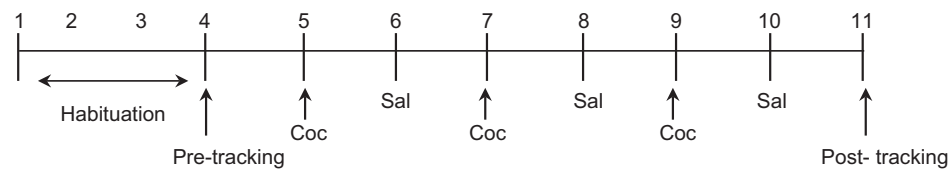

b

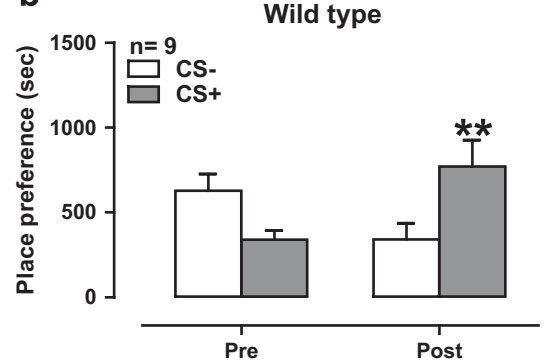

d

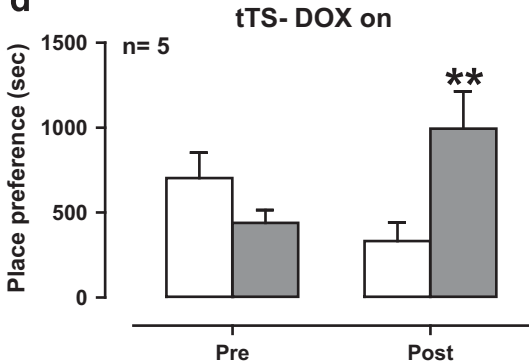

c

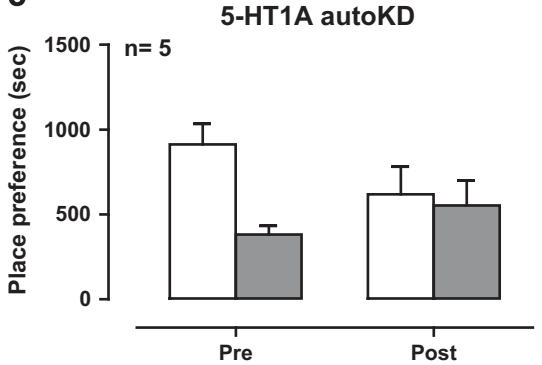

e

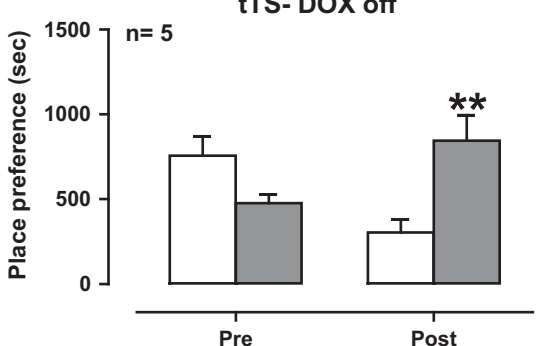

Figure I Rewarding effects of cocaine in conditional 5-HT IA autoKD mice. (a) Scheme of the cocaine-induced conditioned place preference (CPP) test. Effects of $7.5 \mathrm{mg} / \mathrm{kg}$ cocaine on CPP in wild-type mice (b), 5-HTIA autoKD mice (c), tTS ${ }^{-}$DOX-ON mice (d), and tTS ${ }^{-}$DOX-OFF mice (e). * $^{*} P<<0.01$, CS- of post-test vs CS+ of post-test. 5-HTIA autoKD, 5-HTIA autoreceptor knockdown; CS, conditioned stimulus (cocaine); DOX-OFF, mice fed regular chow; DOX-ON, mice fed doxycycline chow; tTS, tetracycline-dependent transcriptional suppressor.

To further address whether the injection of $\mathrm{CNO}$ activated the 5-HT neurons of hM3Dq-expressing mice, we measured c-fos immunoreactivity, a marker of cellular activation, in the NAc slices prepared from hM3Dq-expressing mice and non-cre-expressing littermates 90 min after injection of $\mathrm{CNO}$ $(1 \mathrm{mg} / \mathrm{kg})$. CNO injection significantly increased c-fos immunoreactivity in SERT-expressing neurons in the DRN (Figure $2 \mathrm{c}-\mathrm{e} ; t=2.75, \mathrm{df}=10, P<0.05$ ) and the NAc (Figure $2 \mathrm{f}-\mathrm{h} ; t=2.32, \mathrm{df}=8, P<0.05)$ of the hM3Dq-expressing Cre + mice compared with those in Cre- mice. These findings confirm that Cre activity is required to enable hM3Dq and hM4Di expression in 5-HT neurons and CNO administration is directly linked to the stimulation of hM3Dqexpressing 5-HT neuronal activity.

\section{Activation of 5-HT Neurons by DREADDs Abolishes Cocaine-Induced CPP}

To test the hypothesis that $\mathrm{DRN} \rightarrow \mathrm{NAc} 5$-HT neuron activity modulates cocaine reward, we activated or inhibited neurons with $\mathrm{Gq}$ or $\mathrm{Gi}$ DREADD via $\mathrm{CNO}$ before cocaine training. The timeline of the AAV injection and CPP, as well as EPM, TST, locomotor activity, and perfusion for immunoreactivity (described below), is shown in Figure 3a. In the CPP assay, mice received systemic injection of $\mathrm{CNO}$ ( $1 \mathrm{mg} / \mathrm{kg}$ ) $20 \mathrm{~min}$ before cocaine or saline training. Stimulation of 5-HT neurons from the DRN $\rightarrow$ NAc via injection of CNO prevented CPP induced by cocaine $(7.5 \mathrm{mg} / \mathrm{kg}$ i.p.) in
hM3Dq-expressing Cre+ mice (Figure 3b; Stimulus $\times$ Test interaction $F_{1,14}=2.15, P=0.17$; Stimulus $F_{1,14}=1.13$, $P=0.31$; Test $\left.\mathrm{F}_{1,14}=0.63, P=0.44\right)$, whereas WT mice (Cre-) with CNO displayed CPP for cocaine (Figure 3e; Stimulus $\times$ Test interaction $\mathrm{F}_{1,12}=17.85, P<0.01$; Stimulus $\mathrm{F}_{1,12}=2.87, P=0.12$; Test $\left.\mathrm{F}_{1,12}=0.03, P=0.87\right)$. Next, we examined whether inhibition of 5-HT neurons from the $\mathrm{DRN} \rightarrow \mathrm{NAc}$ potentiated a CPP induced by low-dose cocaine $(4 \mathrm{mg} / \mathrm{kg})$ in hM4Di-expressing mice. Cocaine $(4 \mathrm{mg} / \mathrm{kg})$ conditioned a low level of place preference in both Cre+ and Cre - mice (Figure 3c; Stimulus $\times$ Test interaction $\mathrm{F}_{1,12}=31.94, P<0.001$; Stimulus $\mathrm{F}_{1,12}=2.97, P=0.11$; Test $\mathrm{F}_{1,12}=0.01, P=0.92$; Figure $3 \mathrm{f}$; Stimulus $\times$ Test interaction $\mathrm{F}_{1,10}=11.86, P<0.01$; Stimulus $\mathrm{F}_{1,10}=3.82, P=0.08$; Test $\left.\mathrm{F}_{1,10}=0.30, P=0.59\right)$. The CPP induced by $4 \mathrm{mg} / \mathrm{kg}$ cocaine was neither potentiated nor reduced by the inhibition of 5-HT neurons from the DRN $\rightarrow$ NAc. Thus, inhibiting hM4Diexpressing 5-HT neurons with CNO had no effect on cocaineinduced CPP (Figure 3c). Both control virus (Blank) expressing Cre+ mice and Cre- mice showed cocaine (7.5 mg/kg i.p.)-induced CPP (Figure 3d; Stimulus $\times$ Test interaction $\mathrm{F}_{1,12}=7.01, \quad P<0.05$; Stimulus $\mathrm{F}_{1,12}=9.31$, $P<0.05$; Test $\mathrm{F}_{1,12}=0.00, P=0.97$; Figure 3g; Stimulus $\times$ Test interaction $\mathrm{F}_{1,12}=19.72, \quad P<0.01$; Stimulus $\mathrm{F}_{1,12}=5.25$, $P<0.05 ;$ Test $\left.\mathrm{F}_{1,12}=0.11, P=0.75\right)$. Together, these data indicate that increasing, but not decreasing, DRN $\rightarrow$ NAc serotonergic neuron activity reduces cocaine reward. 
a
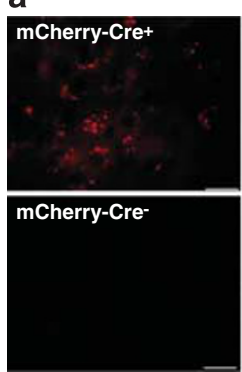

c
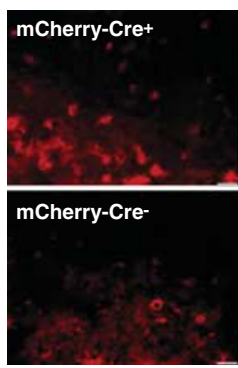

f

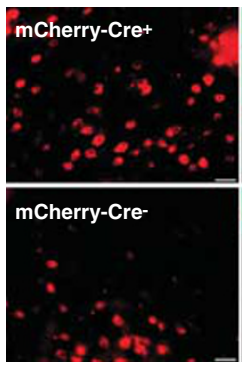

DRN
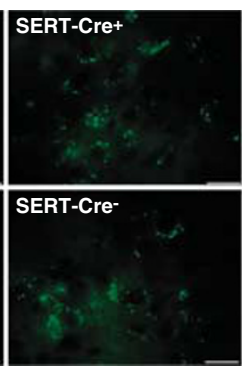
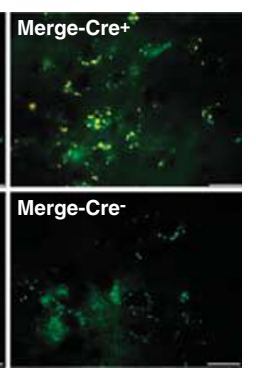

b
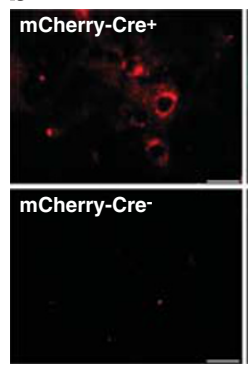

DRN
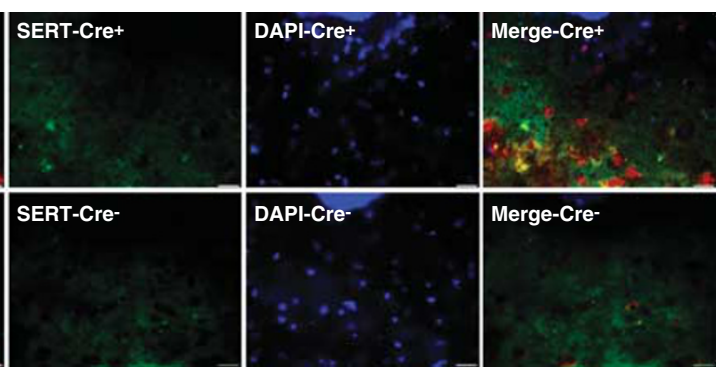

d
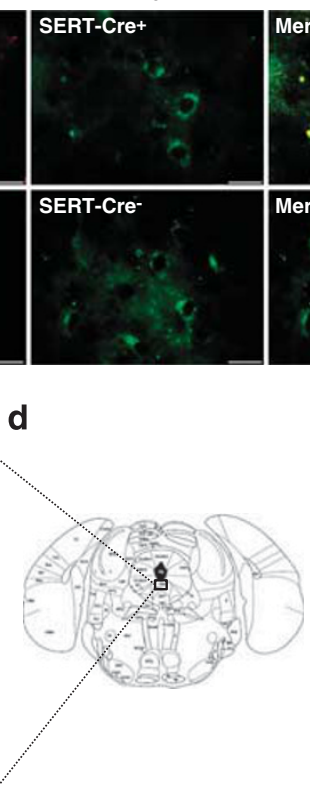

g
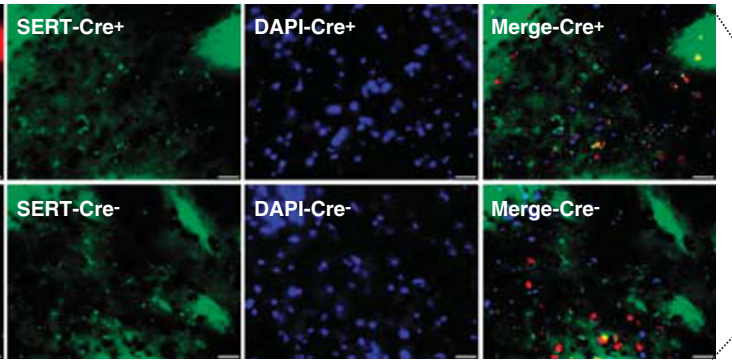

NAc

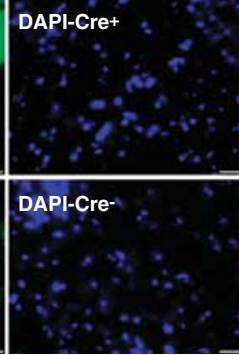

.

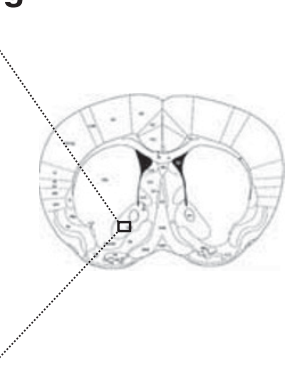

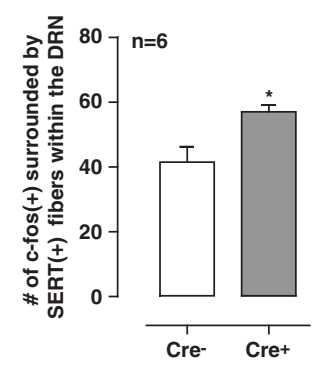

h

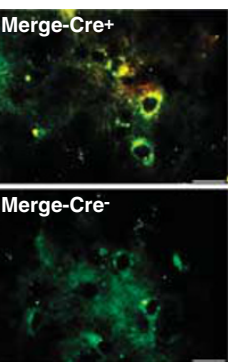

e

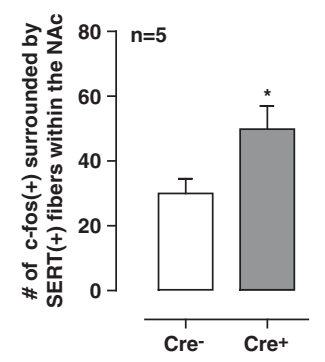

Figure 2 Expression of DREADDs in the DRN and NAc projections and c-fos immunoreactivity in the NAc by $C N O$ in Fev-cre mice. Immunofluorescence labeling for AAV8-hSyn-DIO-hM3D(Gq)-mCherry (red) and serotonin transporter (green) in the DRN (a) and the NAc (b) in Cre+ mice and Cre- mice. Immunofluorescence labeling for c-fos (red), serotonin transporter (green) and DAPI (blue) in the DRN (c) and the NAc (f) in the Cre+ mice and Cre- mice. Schematic indicating the site of the imaged area in the DRN (d) and the NAc (g). Injection of CNO in vivo increases c-fos immunoreactivity in the DRN (e) and the NAc (h) of the Cre+ mice compared with Cre- mice. $* P<0.05$, Cre+ vs Cre-. Brains were obtained for c-fos analysis 90 min following injection of CNO (I mg/kg of body weight, i.p.). Scale bars: $20 \mu \mathrm{m}$. CNO, clozapine-N-oxide; Cre+, Fev-cre transgenic mice; Cre- , their littermates and non-cre-expressing mice; SERT, serotonin transporter.

\section{Stimulation of 5-HT Neurons by DREADDs Leads to Antidepressive Behavior}

At 1 week after CPP testing, we investigated whether activation of 5-HT neurons affects anxiety- and depression-like behaviors, comorbid with drug addiction (Araos et al, 2014), using the EPM and TST. In the EPM test, neither genotype nor CNO $(1 \mathrm{mg} / \mathrm{kg})$ injection had significant effects on the number of entries into the open arms and the time spent in the open arms (Supplementary Figure S1a; $t=0.36, \mathrm{df}=13, P=0.72$; Supplementary Figure S1b; $t=1.41, \mathrm{df}=12, P=0.18$; Supplementary Figure S1c; $t=0.42, \mathrm{df}=12, P=0.68$; Supplementary Figure S1d; $t=1.04$, $\mathrm{df}=13, P=0.32$; Supplementary Figure $\mathrm{S} 1 \mathrm{e} ; t=0.15, \mathrm{df}=12$, $P=0.88 ; \quad$ Supplementary Figure S1f; $t=1.13, \mathrm{df}=12$, $P=0.28)$. In the TST test, CNO $(1 \mathrm{mg} / \mathrm{kg})$ significantly decreased the immobility time in the Cre+ mice expressing stimulatory hM3Dq DREADDs in 5-HT neurons compared with Cre- mice (Figure $3 \mathrm{~h} ; t=2.50, \mathrm{df}=13, P=0.03$ ). $\mathrm{CNO}$ did not significantly affect immobility time in Cre+ mice expressing hM4Di inhibitory DREADDs compared with control virus-expressing Cre+ mice in DRN $\rightarrow$ NAc 5 -HT neurons (Figure $3 \mathrm{i} ; t=0.57, \mathrm{df}=12, P=0.58$; Figure $3 \mathrm{j}$; $t=0.35, \mathrm{df}=12, P=0.74)$. We also measured the time spent immobile for the first $2 \mathrm{~min}$, because mice showed the first immobility between 80 and $100 \mathrm{~s}$ on average (Francis et al, 2012; Vollenweider et al, 2011). There was no significant difference between Cre+ and Cre- mice expressing DREADDs in the time spent immobile for the first $2 \mathrm{~min}$ (Supplementary Figure S2a; $t=1.67, \quad \mathrm{df}=13, \quad P=0.12$; Supplementary Figure S2b; $t=0.94, \quad \mathrm{df}=11, \quad P=0.37$; Supplementary Figure S2c; $t=1.14, \mathrm{df}=13, P=0.28)$. CNO injection (1 mg/kg, i.p.) had no effect on locomotor activity, as indicated by the total traveled distance in all groups (Supplementary Figure S3a; Cre $\times$ Time interaction $\mathrm{F}_{4,56}=0.69, \quad P=0.60 ; \quad$ Cre $\mathrm{F}_{1,14}=0.67, \quad P=0.43$; Time $\mathrm{F}_{4,56}=10.43, P<0.001$; Supplementary Figure S3b; Cre $\times$ Time interaction $\mathrm{F}_{4,52}=1.78, P=0.15 ;$ Cre $\mathrm{F}_{1,13}=0.00$, 

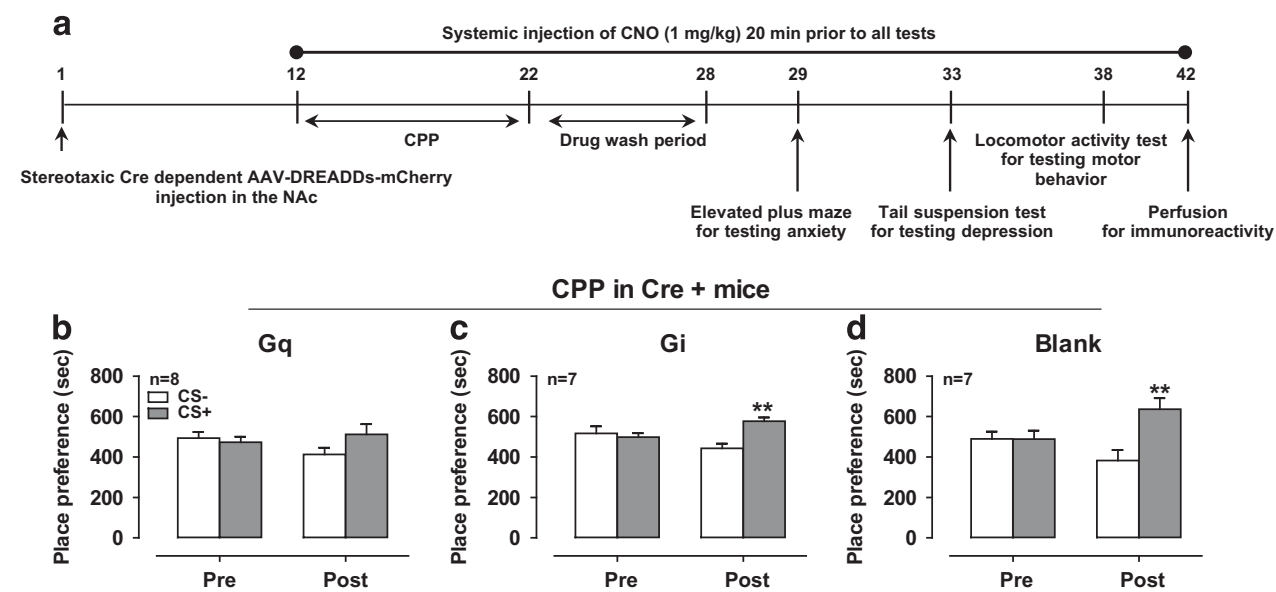

CPP in Cre + mice
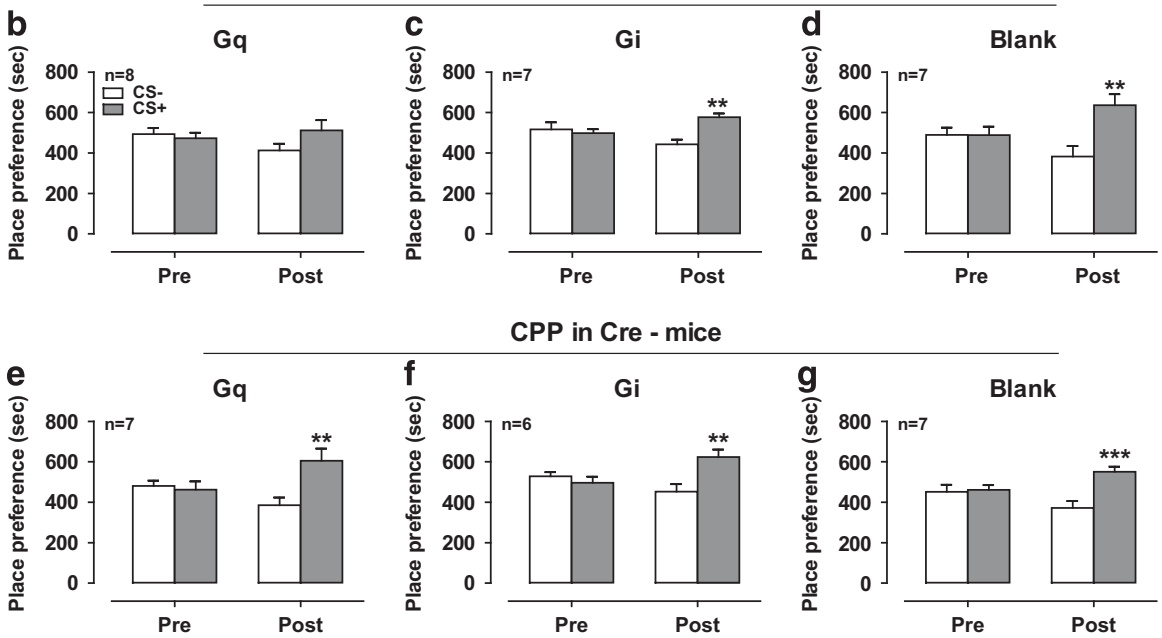

TST in Cre + and Cre - mice
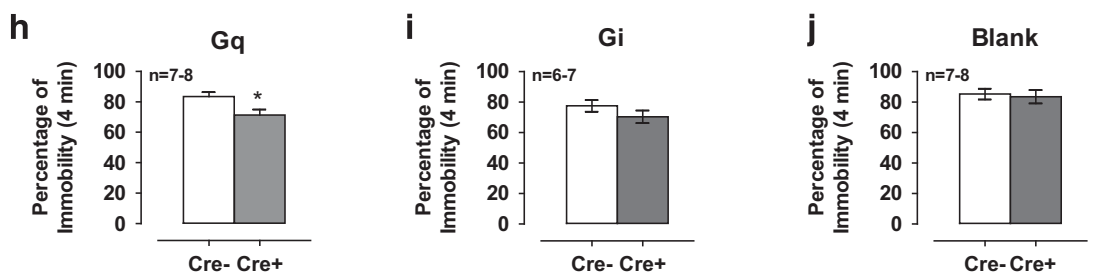

Figure 3 Excitation of the DRN $\rightarrow$ NAc 5-HT projection by DREADDs abolished cocaine-induced CPP and produced antidepressant-like behaviors. Gqand blank-DREADD-expressing mice received $7.5 \mathrm{mg} / \mathrm{kg}$ cocaine, whereas Gi-DREADD-expressing mice received $4 \mathrm{mg} / \mathrm{kg}$ cocaine. (a) Timeline of AAV microinjection and behavioral tests. Effect of cocaine on CPP in Cre+ mice expressing Gq-DREADD (b), Gi-DREADD (c), and blank-DREADD (d). Effect of cocaine on CPP in Cre- mice expressing Gq-DREADD (e), Gi-DREADD ( $\mathrm{f}$ ), and blank-DREADD (g). $* *$ * $P<0.0$ I, ***** $P<0.00$ I, CS - of post-test vs CS+ of post-test. Effect of CNO (I mg/kg, i.p.) injection on TST in Cre+ and Cre- mice expressing Gq-DREADD, (h) Gi-DREADD (i), and blank-DREADD (j). ${ }^{*} P<0.05$, Cre+ vs Cre- . Cre+, Fev-cre transgenic mice; Cre-, their littermates and non-cre-expressing mice.

$P=0.95 ; \quad$ Time $\quad \mathrm{F}_{4,52}=20.10, \quad P<0.001 ; \quad$ Supplementary Figure S3c; Cre $\times$ Time interaction $\mathrm{F}_{4,48}=0.29, P=0.89$; Cre $\mathrm{F}_{1,12}=1.61, P=0.23$; Time $\mathrm{F}_{4,48}=34.54, P<0.001$ ).

\section{5-HT 1 A Receptor Inhibition Attenuates Increased Motivation for Cocaine in LgA Rats}

The timeline of the surgery, self-administration training, grouping for ShA and LgA, and test for drugs is shown in Figure 4a. The $\operatorname{LgA}$ rats exhibited an increase in cocaine intake with 6-h access under a fixed ratio (FR) schedule of reinforcement during an entire session as well as during the first hour of a session, whereas ShA rats maintained a constant level of intake (Figure 4b; Session intake, Session $\times$ Access interaction $\quad F_{14,224}=1.9, \quad P<0.05 ; \quad$ Session $\mathrm{F}_{14,224}=10.0, \quad P<0.001 ;$ Access $\mathrm{F}_{1,224}=19.0, \quad P<0.001$; Figure 4c; First hour intake, Session $\times$ Access interaction $\mathrm{F}_{14,224}=8.2, \quad P<0.001$; Session $\mathrm{F}_{14,224}=16.8, \quad P<0.001$; Access $\left.\quad \mathrm{F}_{1,224}=22.1, \quad P<0.001\right)$. LgA rats also self-administered more cocaine than ShA rats under a PR schedule, achieving a higher response ratio per cocaine injection (Figure $4 \mathrm{~d}$ and e). In the PR schedule, the response requirement per drug injection gradually increases within a session, measuring the amount of work that an animal is willing to exert for a drug injection. The ratio/ reward on the right $y$ axis was matched with injection number according to the following equation: responses/ injection $=\left[5 \times \mathrm{e}^{(\text {injection number } \times 0.2)}\right]-5 \quad$ (Richardson and Roberts, 1996). The data suggest that LgA rats had higher motivation for cocaine self-administration than ShA rats. We tested the effects of a selective $5-\mathrm{HT}_{1 \mathrm{~A}}$ receptor antagonist, WAY100635, on cocaine self-administration under a PR schedule. Systemic injection of WAY100635 decreased cocaine self-administration only in LgA rats under a PR schedule (Figure 4d; WAY100635 Dose $\times$ Access interaction $\mathrm{F}_{4,64}=0.9, P>0.05$; WAY100635 dose $\mathrm{F}_{4,64}=5.5, P<0.001$; Access $\mathrm{F}_{1,64}=7.9, P=0.01$ ).

To test the hypothesis that the effect of WAY100635 on cocaine intake is mediated through DRN $5-\mathrm{HT}_{1 \mathrm{~A}}$ receptors, we implanted cannulas targeting the DRN and microinfused 
a

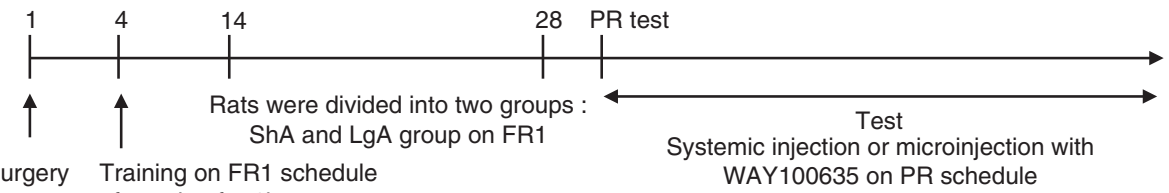

Surgery Training on FR1 schedule of cocaine for $1 \mathrm{~h}$

b

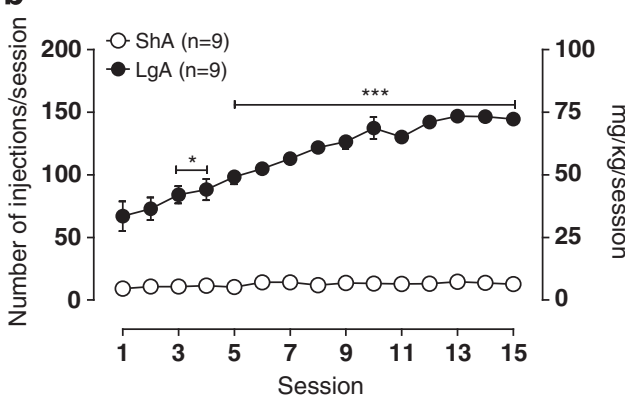

d

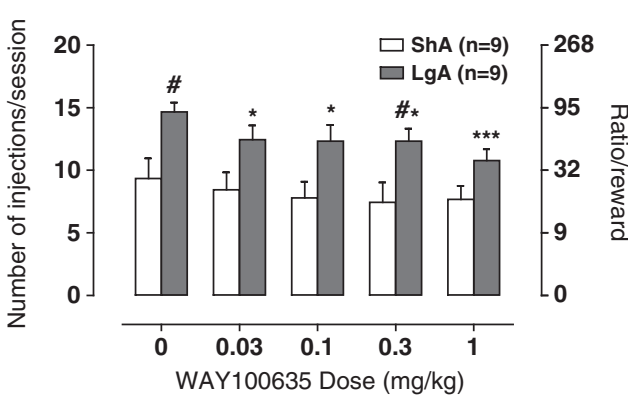

C
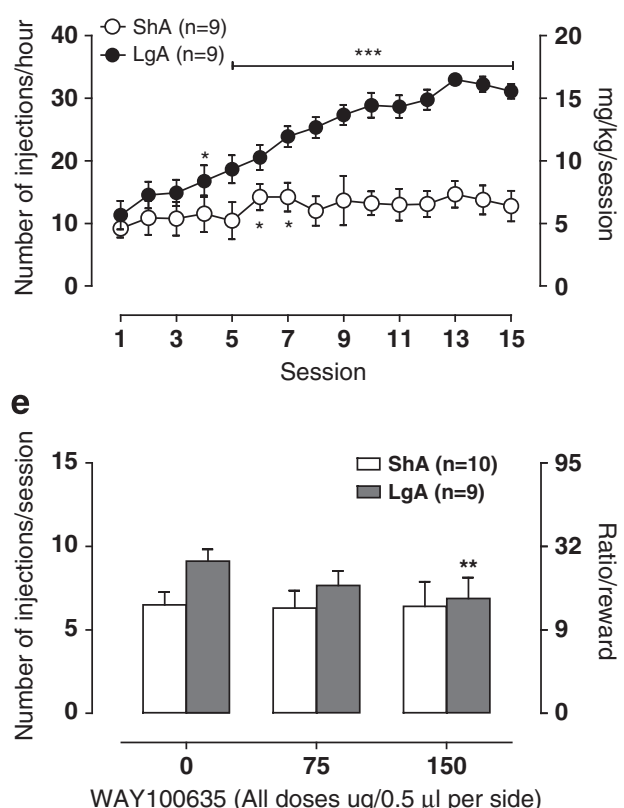

Figure $45-\mathrm{HT}_{I A}$ autoreceptor inhibition attenuated the heightened motivation for cocaine self-administration in a rat model of cocaine addiction. (a) Scheme of testing the effect of WAYI00635, a 5-HT IA receptor antagonist, on cocaine self-administration under PR. (b) Entire-session cocaine selfadministration with short access (ShA) and extended access ( $\mathrm{LgA})$ in rats that were tested with systemic injection of WAY I00635. $* P<0.05$, $* * * * P<0.00$ I, compared with session I. (c) The first hour of cocaine self-administration in ShA and LgA rats that received a systemic injection of WAY I00635. *P $<0.05$, **** $P<0.001$, compared with session I. (d) Systemic injection effect of various doses of WAY 100,635 on cocaine self-administration under a PR schedule. ${ }^{*} P<0.05$, ***P $<0.00$ I, compared with 0.5X phosphate-buffered saline (PBS; zero dose); ${ }^{*} P<0.05$, compared with ShA group. (e) Intradorsal raphe infusion effect of WAY I00,635 on cocaine self-administration under a PR schedule. ${ }^{*} * P<0.01$, compared with zero dose.

the drug into the DRN during PR schedule responding in ShA and LgA rats. In cannulated rats, cocaine selfadministration remained constant with daily $1 \mathrm{~h}$ access in ShA rats but increased with daily $6 \mathrm{~h}$ access in LgA rats (Supplementary Figure S4a; Session intake, Session $\times$ Access interaction $\mathrm{F}_{11,187}=5.91, P<0.001$; Session $\mathrm{F}_{11,187}=11.48$, $P<0.001$; Access $\left.\mathrm{F}_{1,17}=63.92, P<0.001\right)$ similar to selfadministration in noncannulated animals. Microinjection of WAY100635 into the DRN decreased cocaine selfadministration under a PR schedule in LgA rats (Figure 4e; WAY100635 dose $\times$ Access interaction $\mathrm{F}_{2,34}=1.98$, $P=0.1532$; WAY100635 dose $\mathrm{F}_{2,34}=5.17, P<0.05$; Access $\left.\mathrm{F}_{1,17}=1.06, P=0.32\right)$. WAY100635 $(150 \mu \mathrm{g})$ significantly decreased cocaine self-administration in $\operatorname{LgA}$ rats under a PR schedule compared with the vehicle treatment $(P<0.01)$. The drug did not alter cocaine self-administration at any dose in ShA rats.

\section{DISCUSSION}

In this study, we tested the hypothesis that increased activity of $5-\mathrm{HT}_{1 \mathrm{~A}}$ autoreceptors induced by chronic cocaine use is a key neural mechanism that contributes to transition to cocaine addiction. We found that deletion of $5-\mathrm{HT}_{1 \mathrm{~A}}$ autoreceptors in the DRN from birth abolished the rewarding effect of cocaine in mice. Using DREADDs, we also showed that stimulation of DRN $\rightarrow$ NAc 5 -HT projections, which essentially mimics the effect of $5-\mathrm{HT}_{1 \mathrm{~A}}$ autoreceptor knockdown, abolished cocaine-induced CPP. In addition, stimulation of DRN $\rightarrow$ NAc 5-HT neurons produced antidepressive-like behavior in the TST. Finally, we found that the inhibition of $5-\mathrm{HT}_{1 \mathrm{~A}}$ receptors specifically in the DRN selectively attenuated the increased motivation for cocaine in $\operatorname{LgA}$ rats, suggesting a positive relationship between the increase in $5-\mathrm{HT}_{1 \mathrm{~A}}$ receptor activity and the transition to compulsive-like cocaine self-administration.

Few selective pharmacological tools are available to differentiate $5-\mathrm{HT}_{1 \mathrm{~A}}$ auto- and heteroreceptors. Recently, conditional 5- $\mathrm{HT}_{1 \mathrm{~A}}$ autoreceptor knockdown mice have been generated, serving as an invaluable tool to study $5-\mathrm{HT}_{1 \mathrm{~A}}$ autoreceptors (Richardson-Jones et al, 2011). Using these transgenic mice, we tested the role of $5-\mathrm{HT}_{1 \mathrm{~A}}$ autoreceptors in cocaine reward. Our data suggest that $5-\mathrm{HT}_{1 \mathrm{~A}}$ autoreceptors play a role in the development of cocaine addiction and that the high activity of $5-\mathrm{HT}_{1 \mathrm{~A}}$ autoreceptors, and consequent low serotonin neuron activity, may convey 
vulnerability to cocaine addiction by increasing the sensitivity to cocaine reward.

In our experiments using $5-\mathrm{HT}_{1 \mathrm{~A}}$ autoKD and control mice, we used a biased subject assignment procedure such that animals were paired with a rewarding stimulus (unconditioned stimulus (US)) in the least-preferred compartment. This was done because this mouse line exhibited a significant chamber preference during the CPP pre-test (Figure 1) and previous studies suggest that although pairing the US with the least-preferred chamber elicits a CPP, a preference fails to develop when the US is paired with the preferred side in animals with a significant chamber bias during the pre-test (Calcagnetti and Schechter, 1994). Thus, randomly assigning compartments to be paired with rewarding stimuli without assessing baseline preferences may not result in a CPP (Prus et al, 2009). In contrast, we used an unbiased design for the Fev-cre mouse line because they did not show a significant difference between times spent in the two compartments during the pre-test. Although the cocaine (US) effects in a biased subject assignment procedure may be attributed to a reduction of the subject's initial unlearned preference, rather than a direct measure of reward, cocaine elicited a significant place preference in all control groups, making this possibility unlikely.

A previous study showed that the serotonergic system was activated when $5-\mathrm{HT}_{1 \mathrm{~A}}$ autoreceptor levels were reduced in adulthood using the $5-\mathrm{HT}_{1 \mathrm{~A}}$ autoKD mice. These mice exhibited a higher raphe firing rate compared with control mice, presumably because of their lower raphe firing rate via activation of 5- $\mathrm{HT}_{1 \mathrm{~A}}$ autoreceptors (Richardson-Jones et al, 2010). The enhanced raphe firing rate by the reduction of 5$\mathrm{HT}_{1 \mathrm{~A}}$ autoreceptor function could increase resilience to chronic stress and addiction by increasing serotonergic tone in forebrain regions. Our data from stimulation of DRN $\rightarrow$ NAc 5-HT projections via DREADDs, which mimics the decrease of $5-\mathrm{HT}_{1 \mathrm{~A}}$ autoreceptor function on neuronal activity, provide direct evidence for this possibility. Using this model, activation of $\mathrm{DRN} \rightarrow \mathrm{NAc} 5$-HT projections reduced cocaine reward and antidepressive-like behavior. Therefore, these data suggest that development of cocaine reward and depression are associated with increased $5-\mathrm{HT}_{1 \mathrm{~A}}$ autoreceptor function in the DRN, resulting in decreased 5 -HT output to the NAc. Stimulation of DRN $\rightarrow$ NAc 5-HT neurons did not affect anxiety-like or locomotor behaviors. Because CNO had no effect on locomotor activity within $20 \mathrm{~min}$, the time required for CNO to activate DREADDs in the brain after injection (Alexander et al, 2009; Rogan and Roth, 2011), it is unlikely that the decrease in immobility time in the TST and the abolishment of cocaine CPP is a secondary effect of DRN $\rightarrow$ NAc 5 -HT neuron stimulation on locomotor activity.

Previous studies showed that intra-DRN 5- $\mathrm{HT}_{1 \mathrm{~A}}$ receptor agonist injection conditioned a place preference (Fletcher et al, 1993) and caused a potentiation of acute cocaineinduced motor activity (Szumlinski et al, 2004). In contrast, our data on the effect of inhibition of DRN $\rightarrow$ NAc 5-HT neurons, which mimics the activation of $5-\mathrm{HT}_{1 \mathrm{~A}}$ autoreceptors in the DRN, showed no potentiating effect of reducing DRN 5-HT neuron activity on cocaine reward. This discrepancy can likely be explained by the specificity of our experimental design that selectively targets DRN 5-HT neurons themselves, whereas pharmacological manipulations will yield contributions from $5-\mathrm{HT}_{1 \mathrm{~A}}$ receptor activation in both 5-HT and non-5-HT DRN neurons. Szumlinski et al (2004) also showed that microinjection of $5-\mathrm{HT}_{1 \mathrm{~A}}$ receptor agonist in the DRN enhanced the level of both extracellular dopamine and glutamate in the NAc. Thus, CPP and enhanced cocaine-induced hyperlocomotion via pharmacological activation of $5-\mathrm{HT}_{1 \mathrm{~A}}$ receptors in the $\mathrm{DRN}$ might involve the dopamine and glutamate systems. Indeed, recent studies have provided evidence that optogenetic stimulation of the DRN cell bodies reinforce behaviors in a 5-HT-independent manner with non-5-HT neurons in the DRN, providing glutamatergic input to ventral tegmental area dopamine neurons (McDevitt et al, 2014). These findings indicate that $5-\mathrm{HT}_{1 \mathrm{~A}}$ heteroreceptor expression in DRN non-5-HT neurons (Beck et al, 2004) might contribute to this circuit in cocaine reward. Our results suggest that exclusive inhibition of $\mathrm{DRN} \rightarrow \mathrm{NAc} 5-\mathrm{HT}$ neurons via activation of $5-\mathrm{HT}_{1 \mathrm{~A}}$ autoreceptors may not be sufficient to affect cocaine reward. Although we did not perform CPP with a higher dose of cocaine in the Gi-DREADD mice, our data indicate that a low dose of cocaine $(4 \mathrm{mg} / \mathrm{kg})$ was neither potentiated nor decreased by inhibition of DRN 5-HT neurons. Thus, inhibiting hM4Di-expressing 5-HT neurons with $\mathrm{CNO}$ may have little effect on higher dose of cocaine-induced CPP.

Based on our findings, we tested the hypothesis that increased DRN $\rightarrow$ NAc 5-HT neuron activity via blockade of $5-\mathrm{HT}_{1 \mathrm{~A}}$ receptors may promote resiliency to cocaine addiction-related behavior by using a rodent model of selfadministration with extended access to the drug. Rats with extended access to cocaine self-administration exhibited an increase in cocaine self-administration under both FR and PR schedules that mimics the development of tolerance to the drug and increased motivation to take the drug in humans who compulsively seek drugs (Ahmed and Koob, 1998; Wee et al, 2007a, b). Furthermore, previous studies demonstrated that $\operatorname{LgA}$ rats exhibited dysphoric- and anxiety-like withdrawal states compared with ShA rats (Ahmed et al, 2002; Aujla et al, 2008). One hypothesis for the development of addiction is that negative withdrawal symptoms, such as dysphoria and anxiety, drive compulsive drug seeking and relapse to drug use (Koob et al, 1997; Koob and Le Moal, 2008). Indeed, LgA rats were more sensitive to the reinstatement of extinguished responding for cocaine self-administration upon re-exposure to a priming cocaine injection than ShA rats (Knackstedt and Kalivas, 2007; Mantsch et al, 2004), suggesting an increase in the vulnerability to relapse. Therefore, this rodent model is a valuable tool to investigate the neural mechanisms of cocaine addiction.

A previous study reported that $0.5 \mathrm{mg} / \mathrm{kg} 8-\mathrm{OH}-\mathrm{DPAT}$, a $5-\mathrm{HT}_{1 \mathrm{~A}}$ receptor agonist, decreased self-administration of a low unit dose of cocaine in rats with $2 \mathrm{~h}$ access (Peltier and Schenk, 1993). The literature suggests that $0.05 \mathrm{mg} / \mathrm{kg}$ or a higher dose of $8-\mathrm{OH}-\mathrm{DPAT}$ stimulates both $5-\mathrm{HT}_{1 \mathrm{~A}}$ auto- and heteroreceptors, based on microdialysis and physiological data (Allen et al, 1997; Chen and Reith, 1995). Moreover, the activation of $5-\mathrm{HT}_{1 \mathrm{~A}}$ heteroreceptors in the forebrain has been hypothesized to enhance mood (Blier and Ward, 2003; Gross et al, 2002; Le Francois et al, 2008). Thus, the activation of $5-\mathrm{HT}_{1 \mathrm{~A}}$ heteroreceptors by a high dose of 8-OH-DPAT via enhanced reward might be related 
to the decreased motivation for cocaine self-administration in rats. However, our data showed that systemic inhibition of $5-\mathrm{HT}_{1 \mathrm{~A}}$ receptors with WAY100635 selectively attenuated the increased motivation for cocaine in $\operatorname{LgA}$ rats. The doses of WAY100635 $(0.03-0.3 \mathrm{mg} / \mathrm{kg})$ appeared to preferentially act on $5-\mathrm{HT}_{1 \mathrm{~A}}$ autoreceptors, in which $0.4 \mathrm{mg} / \mathrm{kg}$ of the drug was shown to augment the cocaine-induced increase in 5-HT levels in the NAc and hippocampus (Muller et al, 2002a, b). This suggests that $0.4 \mathrm{mg} / \mathrm{kg}$ WAY100635 blocked the inhibitory action of $5-\mathrm{HT}_{1 \mathrm{~A}}$ autoreceptors within the DRN, resulting in an increase in 5-HT release. To confirm this possibility, we microinjected WAY100635 into the DRN and found that it also decreased cocaine self-administration under a PR schedule in LgA rats but not in ShA rats, consistent with our data from a mouse model of cocaine reward. Previous electrophysiological studies have reported hypersensitivity of $5-\mathrm{HT}_{1 \mathrm{~A}}$ autoreceptors in mice during withdrawal from cocaine, ethanol, and 3,4-methylenedioxy$N$-methylamphetamine (Cunningham et al, 1992; Kelai et al, 2008; Renoir et al, 2008). Our data suggest a positive relationship between the increased sensitivity of $5-\mathrm{HT}_{1 \mathrm{~A}}$ autoreceptors and increased motivation for cocaine in addiction.

Cocaine (Mangiavacchi et al, 2001), amphetamine (Kuroki et al, 1996), methamphetamine (Ago et al, 2006), MDMA (ecstacy) (Baumann et al, 2008), morphine/heroin (Tao and Auerbach, 1995), and alcohol (Langen et al, 2002) elicit an acute increase of extracellular 5-HT levels in the brain. Experimental manipulations that reduced 5-HT levels enhanced the majority of behaviors associated with cocaine including hyperlocomotion (Herges and Taylor, 1998) and self-administration (Loh and Roberts, 1990), whereas the techniques to increase extracellular 5-HT activity acutely and chronically differed in their effects on 5-HT systems. Increasing extracellular 5-HT activity pharmacologically attenuated cocaine-induced locomotor response (Molina et al, 2001) and cocaine self-administration (McGregor et al, 1993). The selective serotonin reuptake inhibitor (SSRI), fluoxetine, reduced low doses of cocaine self-administration, but did not affect higher doses of cocaine self-administration (Peltier and Schenk, 1993). Chronic treatment with fluoxetine decreased ethanol self-administration with rapid onset in mice (Gulley et al, 1995) but had limited success in clinical trials for cocaine addiction because of neurobiological changes, including $5-\mathrm{HT}_{2 \mathrm{~A}}$ receptor desensitization, in the frontal cortex (Sawyer et al, 2012). These findings suggest that chronic exposure of abused drugs may induce a functional sequence of serotonergic adaptations (Muller and Homberg, 2015). Chronic exposure to cocaine reduced activity of the 5-HT system leading to an enhanced function of inhibitory 5- $\mathrm{HT}_{1 \mathrm{~A}}$ (Cunningham et al, 1992) and 5- $\mathrm{HT}_{1 \mathrm{~B}}$ autoreceptors (Neumaier et al, 2002). This neuroadaptation may be involved in a long-term reduction in basal 5-HT levels that may further potentiate the addictive effects of cocaine. The reduction in basal 5-HT levels might lead to an increased function of postsynaptic $5-\mathrm{HT}_{2 \mathrm{~A}}$ receptors (Herin et al, 2013) that mediate the reinstatement of cocaine-seeking behavior (Fletcher et al, 2002; Nic Dhonnchadha et al, 2009), and a decreased function of $5-\mathrm{HT}_{2 \mathrm{C}}$ receptors that are involved in stress priming cocaine reinstatement (Fletcher et al, 2008) and anxiety produced by cocaine withdrawal (Craige et al,
2015). Our data from 5- $\mathrm{HT}_{1 \mathrm{~A}}$ autoreceptor knockdown mice, which have higher basal cortical 5-HT levels compared with WT (Richardson-Jones et al, 2011), suggest one therapeutic strategy to reduce cocaine reward may be to increase extracellular 5-HT neuronal activity. As our data indicate that WAY100635 infusion into the DRN reduces cocaine self-administration in rats with long access to the drug, this strategy may be achieved by blocking $5-\mathrm{HT}_{1 \mathrm{~A}}$ autoreceptors with selective antagonists.

\section{CONCLUSION}

We present empirical evidence that increased $5-\mathrm{HT}_{1 \mathrm{~A}}$ autoreceptor activity with chronic cocaine use underlies the enhanced motivation for and sensitivity to compulsive cocaine seeking. Our data indicate that inhibiting or reducing expression of $5-\mathrm{HT}_{1 \mathrm{~A}}$ autoreceptors reduces sensitivity to the rewarding effects of cocaine via selectively increasing $\mathrm{DRN} \rightarrow \mathrm{NAc}$ 5-HT neuron activity. Our data implicate $5-\mathrm{HT}_{1 \mathrm{~A}}$ autoreceptors in the plasticity associated with compulsive-like cocaine seeking. Thus, $5-\mathrm{HT}_{1 \mathrm{~A}}$ autoreceptors may represent a molecular target for therapeutic interventions aimed at alleviating cocaine addiction.

\section{FUNDING AND DISCLOSURE}

The authors declare no conflict of interest.

\section{ACKNOWLEDGMENTS}

We gratefully acknowledge Yanabel Grant and Christine Lynch for their excellent technical assistance. We also thank Jeffrey Sobrieraj and James Heu, undergraduate student interns from the University of California, San Diego, Tara Patton, a National Institute on Drug Abuse undergraduate summer intern, The Scripps FL Mouse Behavior Core, and Maria Mavrikaki, a postdoctoral scholar from The Scripps Research Institute. National Institutes of Health grants DA025785 (to SW), DA004398 (to GFK), DA035371 (to ART and PDG), and MH91427 (to EDL) supported this study. The content is solely the responsibility of the authors and does not necessarily represent the official views of the National Institutes of Health. ALG-G is a recipient of a Spanish Ministry of Science postdoctoral fellowship.

\section{REFERENCES}

Ago Y, Nakamura S, Hayashi A, Itoh S, Baba A, Matsuda T (2006). Effects of osemozotan, ritanserin and azasetron on cocaineinduced behavioral sensitization in mice. Pharmacol Biochem Behav 85: 198-205.

Ahmed SH, Kenny PJ, Koob GF, Markou A (2002). Neurobiological evidence for hedonic allostasis associated with escalating cocaine use. Nat Neurosci 5: 625-626.

Ahmed SH, Koob GF (1998). Transition from moderate to excessive drug intake: change in hedonic set point. Science 282: 298-300.

Albert PR, Fiori LM (2013). Transcriptional dys-regulation in anxiety and major depression: 5-HT1A gene promoter architecture as a therapeutic opportunity. Curr Pharm Des 20: 3738-3750. Alexander GM, Rogan SC, Abbas AI, Armbruster BN, Pei Y, Allen JA et al (2009). Remote control of neuronal activity in 
transgenic mice expressing evolved G protein-coupled receptors. Neuron 63: 27-39.

Allen AR, Singh A, Zhuang ZP, Kung MP, Kung HF, Lucki I (1997). The 5-HT1A receptor antagonist p-MPPI blocks responses mediated by postsynaptic and presynaptic 5-HT1A receptors. Pharmacol Biochem Behav 57: 301-307.

Araos P, Vergara-Moragues E, Pedraz M, Pavon FJ, Campos Cloute R, Calado $\mathrm{M}$ et al (2014). Psychopathological comorbidity in cocaine users in outpatient treatment. Adicciones 26: 15-26.

Armbruster BN, Li X, Pausch MH, Herlitze S, Roth BL (2007). Evolving the lock to fit the key to create a family of $G$ proteincoupled receptors potently activated by an inert ligand. Proc Natl Acad Sci USA 104: 5163-5168.

Aujla H, Martin-Fardon R, Weiss F (2008). Rats with extended access to cocaine exhibit increased stress reactivity and sensitivity to the anxiolytic-like effects of the mGluR 2/3 agonist LY379268 during abstinence. Neuropsychopharmacology 33: 1818-1826.

Baumann MH, Clark RD, Rothman RB (2008). Locomotor stimulation produced by 3,4-methylenedioxymethamphetamine (MDMA) is correlated with dialysate levels of serotonin and dopamine in rat brain. Pharmacol Biochem Behav 90: 208-217.

Beck SG, Pan YZ, Akanwa AC, Kirby LG (2004). Median and dorsal raphe neurons are not electrophysiologically identical. J Neurophysiol 91: 994-1005.

Blier P, Pineyro G, el Mansari M, Bergeron R, de Montigny C (1998). Role of somatodendritic 5-HT autoreceptors in modulating 5-HT neurotransmission. Ann NY Acad Sci 861: 204-216.

Blier P, Ward NM (2003). Is there a role for 5-HT1A agonists in the treatment of depression? Biol Psychiatry 53: 193-203.

Bruchas MR, Schindler AG, Shankar H, Messinger DI, Miyatake M, Land BB et al (2011). Selective p38alpha MAPK deletion in serotonergic neurons produces stress resilience in models of depression and addiction. Neuron 71: 498-511.

Calcagnetti DJ, Schechter MD (1994). Nicotine place preference using the biased method of conditioning. Prog Neuropsychopharmacol Biol Psychiatry 18: 925-933.

Carey RJ, DePalma G, Damianopoulos E, Shanahan A, Muller CP, Huston JP (2005). Evidence that the 5-HT1A autoreceptor is an important pharmacological target for the modulation of cocaine behavioral stimulant effects. Brain Res 1034: 162-171.

Chang B, Daniele CA, Gallagher K, Madonia M, Mitchum RD, Barrett L et al (2011). Nicotinic excitation of serotonergic projections from dorsal raphe to the nucleus accumbens. J Neurophysiol 106: 801-808.

Chen NH, Reith ME (1995). Monoamine interactions measured by microdialysis in the ventral tegmental area of rats treated systemically with (+/-)-8-hydroxy-2-(di-n-propylamino)tetralin. J Neurochem 64: 1585-1597.

Craige CP, Lewandowski S, Kirby LG, Unterwald EM (2015). Dorsal raphe 5-HT(2C) receptor and GABA networks regulate anxiety produced by cocaine withdrawal. Neuropharmacology 93: 41-51.

Cunningham KA, Paris JM, Goeders NE (1992). Chronic cocaine enhances serotonin autoregulation and serotonin uptake binding. Synapse 11: 112-123.

Czoty PW, McCabe C, Nader MA (2005). Effects of the 5-HT(1A) agonist (+/ - )-8-hydroxy-2-(di-n-propylamino)tetralin (8-OHDPAT) on cocaine choice in cynomolgus monkeys. Behav Pharmacol 16: 187-191.

Filip M, Frankowska M, Zaniewska M, Golda A, Przegalinski E (2005). The serotonergic system and its role in cocaine addiction. Pharmacol Rep 57: 685-700.

Fink KB, Gothert M (2007). 5-HT receptor regulation of neurotransmitter release. Pharmacol Rev 59: 360-417.

Fletcher PJ, Grottick AJ, Higgins GA (2002). Differential effects of the 5-HT(2A) receptor antagonist M100907 and the 5-HT(2C) receptor antagonist SB242084 on cocaine-induced locomotor activity, cocaine self-administration and cocaine-induced reinstatement of responding. Neuropsychopharmacology 27: 576-586.
Fletcher PJ, Ming ZH, Higgins GA (1993). Conditioned place preference induced by microinjection of 8-OH-DPAT into the dorsal or median raphe nucleus. Psychopharmacology 113: 31-36.

Fletcher PJ, Rizos Z, Sinyard J, Tampakeras M, Higgins GA (2008). The 5-HT2C receptor agonist Ro60-0175 reduces cocaine selfadministration and reinstatement induced by the stressor yohimbine, and contextual cues. Neuropsychopharmacology 33: 1402-1412.

Francis BM, Yang J, Hajderi E, Brown ME, Michalski B, McLaurin J et al (2012). Reduced tissue levels of noradrenaline are associated with behavioral phenotypes of the TgCRND8 mouse model of Alzheimer's disease. Neuropsychopharmacology 37: 1934-1944.

Gold LH, Balster RL (1992). Effects of buspirone and gepirone on i.v. cocaine self-administration in rhesus monkeys. Psychopharmacology 108: 289-294.

Gross C, Zhuang X, Stark K, Ramboz S, Oosting R, Kirby L et al (2002). Serotonin1A receptor acts during development to establish normal anxiety-like behaviour in the adult. Nature 416: 396-400.

Gulley JM, McNamara C, Barbera TJ, Ritz MC, George FR (1995). Selective serotonin reuptake inhibitors: effects of chronic treatment on ethanol-reinforced behavior in mice. Alcohol 12: 177-181.

Haj-Dahmane S, Hamon M, Lanfumey L (1991). K+ channel and 5-hydroxytryptamine1A autoreceptor interactions in the rat dorsal raphe nucleus: an in vitro electrophysiological study. Neuroscience 41: 495-505.

Hasin D, Liu X, Nunes E, McCloud S, Samet S, Endicott J (2002). Effects of major depression on remission and relapse of substance dependence. Arch Gen Psychiatry 59: 375-380.

Herges S, Taylor DA (1998). Involvement of serotonin in the modulation of cocaine-induced locomotor activity in the rat. Pharmacol Biochem Behav 59: 595-611.

Herin DV, Bubar MJ, Seitz PK, Thomas ML, Hillman GR, Tarasenko YI et al (2013). Elevated expression of serotonin $5-\mathrm{HT}(2 \mathrm{~A})$ receptors in the rat ventral tegmental area enhances vulnerability to the behavioral effects of cocaine. Front Psychiatry 4: 2.

Homberg JR, Arends B, Wardeh G, Raaso HS, Schoffelmeer AN, de Vries TJ (2004). Individual differences in the effects of serotonergic anxiolytic drugs on the motivation to self-administer cocaine. Neuroscience 128: 121-130.

Jacobs BL, Azmitia EC (1992). Structure and function of the brain serotonin system. Physiol Rev 72: 165-229.

Kelai S, Renoir T, Chouchana L, Saurini F, Hanoun N, Hamon M et al (2008). Chronic voluntary ethanol intake hypersensitizes 5HT(1A) autoreceptors in C57BL/6J mice. J Neurochem 107: $1660-1670$.

Kirby LG, Freeman-Daniels E, Lemos JC, Nunan JD, Lamy C, Akanwa A et al (2008). Corticotropin-releasing factor increases GABA synaptic activity and induces inward current in 5-hydroxytryptamine dorsal raphe neurons. J Neurosci 28: 12927-12937.

Kishi T, Tsunoka T, Ikeda M, Kawashima K, Okochi T, Kitajima T et al (2009). Serotonin 1A receptor gene and major depressive disorder: an association study and meta-analysis. J Hum Genet 54: 629-633.

Knackstedt LA, Kalivas PW (2007). Extended access to cocaine self-administration enhances drug-primed reinstatement but not behavioral sensitization. J Pharmacol Exp Ther 322: 1103-1109.

Koob GF, Caine SB, Parsons L, Markou A, Weiss F (1997). Opponent process model and psychostimulant addiction. Pharmacol Biochem Behav 57: 513-521.

Koob GF, Le Moal M (2008). Review. Neurobiological mechanisms for opponent motivational processes in addiction. Philos Trans $R$ Soc Lond B Biol Sci 363: 3113-3123. 
Krashes MJ, Koda S, Ye C, Rogan SC, Adams AC, Cusher DS et al (2011). Rapid, reversible activation of AgRP neurons drives feeding behavior in mice. J Clin Invest 121: 1424-1428.

Kuroki T, Ichikawa J, Dai J, Meltzer HY (1996). R(+)-8-OH-DPAT, a 5-HT1A receptor agonist, inhibits amphetamine-induced serotonin and dopamine release in rat medial prefrontal cortex. Brain Res 743: 357-361.

Land BB, Bruchas MR, Schattauer S, Giardino WJ, Aita M, Messinger D et al (2009). Activation of the kappa opioid receptor in the dorsal raphe nucleus mediates the aversive effects of stress and reinstates drug seeking. Proc Natl Acad Sci USA 106: 19168-19173.

Langen B, Dietze S, Fink H (2002). Acute effect of ethanol on anxiety and 5-HT in the prefrontal cortex of rats. Alcohol 27: $135-141$.

Le Francois B, Czesak M, Steubl D, Albert PR (2008). Transcriptional regulation at a HTR1A polymorphism associated with mental illness. Neuropharmacology 55: 977-985.

Lemos JC, Zhang G, Walsh T, Kirby LG, Akanwa A, Brooks-Kayal A et al (2011). Stress-hyperresponsive WKY rats demonstrate depressed dorsal raphe neuronal excitability and dysregulated CRF-mediated responses. Neuropsychopharmacology 36: 721-734.

Loh EA, Roberts DC (1990). Break-points on a progressive ratio schedule reinforced by intravenous cocaine increase following depletion of forebrain serotonin. Psychopharmacology 101: 262-266.

Mangiavacchi S, Masi F, Scheggi S, Leggio B, De Montis MG, Gambarana C (2001). Long-term behavioral and neurochemical effects of chronic stress exposure in rats. J Neurochem 79: 1113-1121.

Mantsch JR, Yuferov V, Mathieu-Kia AM, Ho A, Kreek MJ (2004). Effects of extended access to high versus low cocaine doses on self-administration, cocaine-induced reinstatement and brain mRNA levels in rats. Psychopharmacology 175: 26-36.

McDevitt RA, Tiran-Cappello A, Shen H, Balderas I, Britt JP, Marino RA et al (2014). Serotonergic versus nonserotonergic dorsal raphe projection neurons: differential participation in reward circuitry. Cell Rep 8: 1857-1869.

McGregor A, Lacosta S, Roberts DC (1993). L-tryptophan decreases the breaking point under a progressive ratio schedule of intravenous cocaine reinforcement in the rat. Pharmacol Biochem Behav 44: 651-655.

Molina PE, Ahmed N, Gatley J, Volkow ND, Abumrad NN (2001). L-tryptophan attenuation of the dopaminergic and behavioral responses to cocaine. Life Sci 69: 1897-1906.

Muller CP, Carey RJ, De Souza Silva MA, Jocham G, Huston JP (2002a). Cocaine increases serotonergic activity in the hippocampus and nucleus accumbens in vivo: 5-HT1a-receptor antagonism blocks behavioral but potentiates serotonergic activation. Synapse 45: 67-77.

Muller CP, De Souza Silva MA, DePalma G, Tomaz C, Carey RJ, Huston JP (2002b). The selective serotonin(1A)-receptor antagonist WAY 100635 blocks behavioral stimulating effects of cocaine but not ventral striatal dopamine increase. Behav Brain Res 134: 337-346.

Muller CP, Homberg JR (2015). The role of serotonin in drug use and addiction. Behav Brain Res 277: 146-192.

Neumaier JF, Vincow ES, Arvanitogiannis A, Wise RA, Carlezon WA Jr (2002). Elevated expression of 5-HT1B receptors in nucleus accumbens efferents sensitizes animals to cocaine. J Neurosci 22: 10856-10863.

Nic Dhonnchadha BA, Fox RG, Stutz SJ, Rice KC, Cunningham KA (2009). Blockade of the serotonin 5-HT2A receptor suppresses cue-evoked reinstatement of cocaine-seeking behavior in a rat self-administration model. Behav Neurosci 123: 382-396.

Peltier R, Schenk S (1993). Effects of serotonergic manipulations on cocaine self-administration in rats. Psychopharmacology 110: 390-394.
Peyron C, Petit JM, Rampon C, Jouvet M, Luppi PH (1998). Forebrain afferents to the rat dorsal raphe nucleus demonstrated by retrograde and anterograde tracing methods. Neuroscience 82: 443-468.

Poling J, Kosten TR, Sofuoglu M (2007). Treatment outcome predictors for cocaine dependence. Am J Drug Alcohol Abuse 33: 191-206.

Popova NK, Naumenko VS (2013). 5-HT1A receptor as a key player in the brain 5-HT system. Rev Neurosci 24: 191-204.

Prus AJ, James JR, Rosecrans JA (2009). Conditioned place preference. In: Buccafusco JJ (ed), Methods of Behavior Analysis in Neuroscience, 2nd edn. CRC Press: Boca Raton (FL).

Renoir T, Paizanis E, El Yacoubi M, Saurini F, Hanoun N, Melfort $M$ et al (2008). Differential long-term effects of MDMA on the serotoninergic system and hippocampal cell proliferation in 5-HTT knock-out vs wild-type mice. Int $J$ Neuropsychopharmacol 11: 1149-1162.

Richardson NR, Roberts DC (1996). Progressive ratio schedules in drug self-administration studies in rats: a method to evaluate reinforcing efficacy. J Neurosci Methods 66: 1-11.

Richardson-Jones JW, Craige CP, Guiard BP, Stephen A, Metzger KL, Kung HF et al (2010). 5-HT1A autoreceptor levels determine vulnerability to stress and response to antidepressants. Neuron 65: 40-52.

Richardson-Jones JW, Craige CP, Nguyen TH, Kung HF, Gardier AM, Dranovsky A et al (2011). Serotonin-1A autoreceptors are necessary and sufficient for the normal formation of circuits underlying innate anxiety. J Neurosci 31: 6008-6018.

Robinson DS, Alms DR, Shrotriya RC, Messina M, Wickramaratne P (1989). Serotonergic anxiolytics and treatment of depression. Psychopathology 22(Suppl 1): 27-36.

Rogan SC, Roth BL (2011). Remote control of neuronal signaling. Pharmacol Rev 63: 291-315.

Sawyer EK, Mun J, Nye JA, Kimmel HL, Voll RJ, Stehouwer JS et al (2012). Neurobiological changes mediating the effects of chronic fluoxetine on cocaine use. Neuropsychopharmacology 37: 1816-1824.

Shelton KL, Hendrick ES, Beardsley PM (2013). Efficacy of buspirone for attenuating cocaine and methamphetamine reinstatement in rats. Drug Alcohol Depend 129: 210-216.

Sprouse JS, Aghajanian GK (1987). Electrophysiological responses of serotoninergic dorsal raphe neurons to 5-HT1A and 5-HT1B agonists. Synapse 1: 3-9.

Stockmeier CA, Shapiro LA, Dilley GE, Kolli TN, Friedman L, Rajkowska G (1998). Increase in serotonin-1A autoreceptors in the midbrain of suicide victims with major depressionpostmortem evidence for decreased serotonin activity. J Neurosci 18: 7394-7401.

Substance Abuse and Mental Health Services Administration, Center for Behavioral Health Statistics and Quality. The DAWN Report:Highlights of the 2010 Drug Abuse Warning Network (DAWN) Findings on Drug-Related Emergency Department Visits. Rockville, MD, 2012.

Substance Abuse and Mental Health Services Administration, Results from the 2012 National Survey on Drug Use and Health: Summary of National Findings, NSDUH Series H-46, HHS Publication No. (SMA) 13-4795. Substance Abuse and Mental Health Services Administration: Rockville, MD, 2013.

Szumlinski KK, Frys KA, Kalivas PW (2004). Dissociable roles for the dorsal and median raphe in the facilitatory effect of 5-HT1A receptor stimulation upon cocaine-induced locomotion and sensitization. Neuropsychopharmacology 29: 1675-1687.

Tao R, Auerbach SB (1995). Involvement of the dorsal raphe but not median raphe nucleus in morphine-induced increases in serotonin release in the rat forebrain. Neuroscience 68: 553-561.

Tomkins DM, Sellers EM, Fletcher PJ (1994). Median and dorsal raphe injections of the 5-HT1A agonist, 8-OH-DPAT, and the GABAA agonist, muscimol, increase voluntary ethanol intake in Wistar rats. Neuropharmacology 33: 349-358. 
Valentino RJ, Lucki I, Van Bockstaele E (2010). Corticotropinreleasing factor in the dorsal raphe nucleus: linking stress coping and addiction. Brain Res 1314: 29-37.

Vollenweider I, Smith KS, Keist R, Rudolph U (2011). Antidepressant-like properties of alpha2-containing GABA(A) receptors. Behav Brain Res 217: 77-80.

Waselus M, Valentino RJ, Van Bockstaele EJ (2011). Collateralized dorsal raphe nucleus projections: a mechanism for the integration of diverse functions during stress. J Chem Neuroanat 41: $266-280$.
Wee S, Mandyam CD, Lekic DM, Koob GF (2007a). alpha(1)-Noradrenergic system role in increased motivation for cocaine intake in rats with prolonged access. Eur Neuropsychopharmacol 18: 303-311.

Wee S, Specio SE, Koob GF (2007b). Effects of dose and session duration on cocaine self-administration in rats. J Pharmacol Exp Ther 320: 1134-1143.

Wess J, Nakajima K, Jain S (2013). Novel designer receptors to probe GPCR signaling and physiology. Trends Pharmacol Sci 34: 385-392.

Supplementary Information accompanies the paper on the Neuropsychopharmacology website (http://www.nature.com/npp) 